\title{
A morphometric analysis of the genus Terschellingia (Nematoda: Linhomoeidae) with redefinition of the genus and key to the species
}

\author{
M. ARMENTERos ${ }^{1,2}$, A. RUIZ-ABIERNO ${ }^{1}$, M. VINCX $^{2}$ AND W. DECRAEMER ${ }^{3,4}$ \\ ${ }^{1}$ Centro de Investigaciones Marinas, Universidad de La Habana, 16 \# 114, CP 11300, Playa, Ciudad Habana, Cuba, ${ }^{2}$ Marine Biology \\ Section, Ghent University, Krijgslaan 281 S8, 9000 Ghent, Belgium, ${ }^{3}$ Department of Invertebrates, Royal Belgian Institute of Natural \\ Sciences, Vautierstraat 29, 1000 Brussels, Belgium, ${ }^{4}$ Nematology Section, Ghent University, Ledeganckstraat 35, 9000 Ghent, Belgium
}

\begin{abstract}
The cosmopolitan and often ecologically dominant genus Terschellingia (Nematoda: Linhomoeidae), with 38 nominal species, is taxonomically a problematic taxon. Its species show high morphological plasticity, possess few diagnostic characters and identification keys are lacking. A revision of the genus was carried out based on morphological and morphometric data from the literature and from observations of specimens collected in Cienfuegos Bay, Caribbean Sea, Cuba. The diagnosis of the genus Terschellingia is emended. Of the current 38 nominal species, 15 are considered as valid species based on morphological characters related to size and position of amphidial fovea, presence/position of cephalic and cervical setae, presence/size/shape of pharyngeal bulb, shape of spicular apparatus and shape of tail. Tabular and pictorial keys were provided based on these characters. Three sympatric species: T. communis, T. gourbaultae and T. longicaudata were redescribed based on recently collected Cuban specimens. Each of them showed relatively large differences in body size in comparison with the respective type specimens, suggesting possible variation due to local environmental differences. The highest intraspecific variation pertains for the most widely spread cosmopolitan species T. longicaudata, suggesting that morphological plasticity enhanced adaptation to different environmental conditions. The notable taxonomic inflation within the genus (14 species inquirendae, 9 junior synonyms), probably also present in other highly specious genera of marine nematodes, can lead to an overestimation of the alpha-diversity.
\end{abstract}

Keywords: morphometric analysis, genus, Terschellingia, redefinition of genus, key to species

Submitted 13 May 2008; accepted 30 December 2008

\section{INTRDDUCTION}

The genus Terschellingia (Nematoda: Linhomoeidae) was erected by de Man (1888) on the basis of the following features: four cephalic setae, buccal cavity small or absent and circular amphidial fovea located far forward on the head region. The etymology of the genus refers to the origin of the type specimens i.e. collected at Terschelling Island in The Netherlands. In general, species pertaining to this genus are cosmopolitan and very often numerically dominant in muddy subtidal bottoms (Heip et al., 1985). Therefore, they play an important ecological role in the sedimentary environment where they inhabit. Despite the notable presence of

Corresponding author:

W. Decraemer

Email: wilfrida.decraemer@ugent.be individuals belonging to the genus Terschellingia in samples from benthic studies, currently, identification to species level remains problematic.

The valuable compilation of free-living marine nematodes by Gerlach \& Riemann (1973) indicated 28 valid species of Terschellingia and six synonymies. The present study describes 38 nominal species and a possible substantial taxonomic inflation (sensu Alroy, 2002). Most of the descriptions of Terschellingia species were carried out by pioneers of nematology (e.g. Cobb, de Man, Filipjev, Gerlach and Timm) dating from more than 50 years ago. This implies the lack of holotypes, the statement of new species on the basis of one or two specimens, often females with relatively few features of taxonomic value. The relatively slow flow of information among researchers in those years and the reduced access to some journals also enhanced the existence of a plethora of synonymies. Three taxonomic keys have been elaborated (Wieser, 
1956; Gerlach, 1963; Austen, 1989), however, these keys do not cover all species of the genus and they are not updated.

The problematic assessment of the genus Terschellingia fits in the larger gap about the taxonomic status of the family Linhomoeidae. The last revision of this family was published by Gerlach (1963) and no further revision has been carried out since. Lorenzen (1994), in his cladistic phylogenetic outline about free-living nematodes, recognized that more extensive analyses are still needed before relationships can be determined.

The 'ideal' taxonomic assessment of any taxon should be based on a phylogenetic approach, combining molecular techniques, like DNA sequence analysis, with morphological data to constitute an appropriate basis for studies of diversity of nematodes (De Ley, 2000; Nadler, 2002). However, the promising application of molecular techniques for delimitation of species currently rests on a preliminary morphological approach (Derycke et al., 2005). A framework of nearly 40 species of Terschellingia, most of them poorly described and morphologically similar, is not the best scenario for: (i) developing an easier way for identification and classification of relevant taxa in order to reduce the taxonomic impediment (De Ley, 2000); and (ii) applying a molecular approach to the taxonomy of the genus. Currently, the exhaustive revision of any taxon of free-living marine nematodes based exclusively on morphology appears in general not enough for a conclusive statement about taxonomy and relationships though it provides a basis for readdressing future studies on particular morph-species and phylogenetic relationships.

The genus Terschellingia possesses relatively few characters of diagnostic value. For example, labial sensilla are reduced (= small), cuticularized structures in buccal cavity as rings or teeth are absent or rarely present, precloacal supplements are rarely present, and the body cuticle lacks ornamentations such as pores or spines. The high morphological plasticity within species of this genus biases to clear identification of morph-species, and is surely related to the cosmopolitan distribution and numerical dominance of the genus in soft bottom habitats. Several appealing features within the genus, such as sperm dimorphism in T. glabricutis (Yushin, 2008) and possible presence of cryptic species in T. longicaudata (Bhadury et al., 2008), are an incentive for the continuation of the studies about the genus Terschellingia. The 'classical' morphological characters used for the diagnosis of species (e.g. relative position of amphidial fovea in the head region, the pattern of somatic setae and tail length) are clearly not sufficient and other morphometric characters were explored in order to refine species diagnoses.

Ecological studies in subtidal muddy bottoms from Cienfuegos Bay, Cuba, Caribbean Sea indicated a notable numerical dominance of the genus Terschellingia in the sediments. Three sympatric species are redescribed in the present study. The aims of this research are: (1) to identify the most important diagnostic features of the genus Terschellingia de Man 1888 and redefine the genus diagnosis; (2) to provide a comprehensive diagnosis of the valid species within the genus; and (3) to construct a pictorial key to species level. Additional information is provided for known species collected in Cuba.

\section{MATERIALS AND METHDDS}

Samples were taken in February 2006 in six subtidal stations from Cienfuegos Bay, Caribbean Sea $\left(22^{\circ} 07^{\prime} \mathrm{N} 80^{\circ} 22^{\prime} \mathrm{W}\right)$. The bay is a semi-enclosed body of water with relatively high organic content in sediment and predominance of muddy bottoms. Samples were collected using hand-held cores and preserved in $8 \%$ buffered formalin. Sediment samples were processed by sieving over two sieves with 500 $\mu \mathrm{m}$ and $45 \mu \mathrm{m}$ mesh size and specimens were extracted by the flotation technique using a high-density sugar solution $\left(1.16 \mathrm{~g} \mathrm{~cm}^{-3}\right)$. Sorted animals were transferred to anhydrous glycerol and mounted on glass slides. The description (including measurements) of the three identified species (T. communis, T. gourbaultae and T. longicaudata) was performed with a contrast phase microscope Leica DMR (maximum magnification $1000 \mathrm{X}$ ) with drawing tube.

Most of the data of the species were collected from original descriptions using the NeMys database (www.nemys.ugent.be; Deprez et al., 2004). From species of which original descriptions lacked relevant morphometric data, measurements were obtained directly from the illustrations. Measuring was carried out by a curvimeter for curvilinear (e.g. body length) and a ruler for straight measurements (e.g. body diameter); the maximum accuracy was $0.5 \mu \mathrm{m}$ in $1000 \mathrm{X}$. We used a rule for measurement of cephalic sensilla length in order to obtain the maximum possible accuracy.

The set of morphometric features considered of taxonomic relevance was mainly based on ratios (Table 1). Ratios were

Table 1. Morphometric features defined for the analysis of the genus Terschellingia.

\begin{tabular}{|c|c|c|}
\hline Code & Measurement & Calculation \\
\hline $\mathrm{L}$ & Body length $(\mu \mathrm{m})$ & \\
\hline$a, b, c$ & de Man's ratios & \\
\hline Amp & Position of amphidial fovea & Distance of end to anterior border of fovea/diameter of fovea \\
\hline Acbd & Size of amphidial fovea & Diameter of fovea expressed in corresponding body diameter \\
\hline Nerv \% & Position of nerve ring & Expressed as percentage of pharynx length \\
\hline Excp \% & Position of excretory-secretory pore & Expressed as percentage of pharynx length \\
\hline Bar & Shape of pharyngeal bulb & Length of bulb/width of bulb \\
\hline $\mathrm{T} \%$ & Length of male reproductive system & Expressed as percentage of body length \\
\hline $\mathrm{V} \%$ & Position of vulva & Distance of end to vulva expressed as percentage of body length \\
\hline G1 \% & Length of anterior genital branch & Length of branch expressed as percentage of body length \\
\hline $\mathrm{G}_{2} \%$ & Length of posterior genital branch & Idem for posterior genital branch \\
\hline Spicl & Length of spicule along arc & Length of spicule along arc/anal body diameter \\
\hline Spicar & Shape of spicule & Length of spicule as curve/length of spicule as cord \\
\hline$c^{\prime}$ & Tail length & Length of the tail/anal body diameter \\
\hline Tcon $\%$ & Length of conical portion of the tail & Length of conical portion of the tail/total length of the tail \\
\hline
\end{tabular}


considered more convenient for comparisons than absolute measurements due to large variability (Fortuner, 1990) and because they were more accurately assessed from original drawings. A set of six morphological features was defined for comparison among species: presence of teeth, position/ presence of cephalic setae, position/presence of cervical setae, presence of pharyngeal bulb, development of gubernaculum apophysis and shape of the tail (conical portion less or larger than $50 \%$ of total length).

The great difference in number of described specimens for each species (i.e. replicates) prevented the application of statistical comparisons and the complete evaluation of the intraspecific variability. For the species reported from the literature only the measurements correspondent to holotype were used, therefore, statistical significance among species could not be tested.

\section{RESULTS AND DISCUSSIDN}

\section{The genus Terschellingia de Man, 1888}

The genus belongs to the family Linhomoeidae (Monhysterida), a taxon of heterogeneous nature without known holapomorphy (Lorenzen, 1994). Three subfamilies are recognized: Desmolaiminae Schneider, 1926, Eleutherolaiminae Gerlach \& Riemann, 1973 and Linhomoeinae Filipjev, 1922. The genus Terschellingia belongs to the Desmolaiminae, a subfamily mainly characterized by (modified from Schneider, 1926): cuticle smooth or faintly annulated, second and third circle of anterior sensilla close $(6+10)$ or separate $(6+6+4)$, amphidial fovea circular, buccal cavity conical and presence of cardia between pharynx and intestine.

Terschellingia, emended diagnosis. Desmolaiminae. Cuticle faintly striated (may appear smooth under light microscope); amphidial fovea rounded. Buccal cavity absent or minute, cuticularized structures (i.e. teeth) rarely present. Pattern of anterior sensilla: $6+6+4$; the labial sensilla only detectable in larger specimens at high magnification and they are almost in the same level that cephalic sensilla; the four cephalic sensilla setiform, submedian and non-jointed. Pharynx shape variable (with or without set off bulb). Cardia valve rather well developed. Secretory-excretory pore located posterior to the nerve ring. Male diorchic, posterior testis reflexed; spicules curved; gubernaculum with apophyses (poorly developed in one species). Female didelphic-amphidelphic (rarely monodelphic-prodelphic), ovaries outstretched, vulva at about mid-body. Tail anteriorly largely conical, posterior part cylindrical and tail tip rounded, without terminal setae.

Type species: Terschellingia communis de Man 1888.

\section{Evaluation of taxonomic diagnostic characters among Terschellingia species}

The examination of six morphological (=qualitative) and 17 morphometric features allowed to detect the characters of diagnostic value within the genus. Scatter plots of selected morphometric features were analysed in order to look for those which discriminate among groups of species (Figure 1). The features related to body size (length and de Man's ratios a and b) not only showed poor discrimination among species but also tend to show high correlation (Fortuner, 1990). In addition, the significant relationship between body dimensions and food availability (dos Santos et al., 2008) suggested the lesser diagnostic value. Features related to relative position and size of amphidial fovea, length of the tail (relative to anal body diameter) and length and shape of spicules allowed discrimination of groups of species (Figure 1) and were therefore considered of diagnostic value.
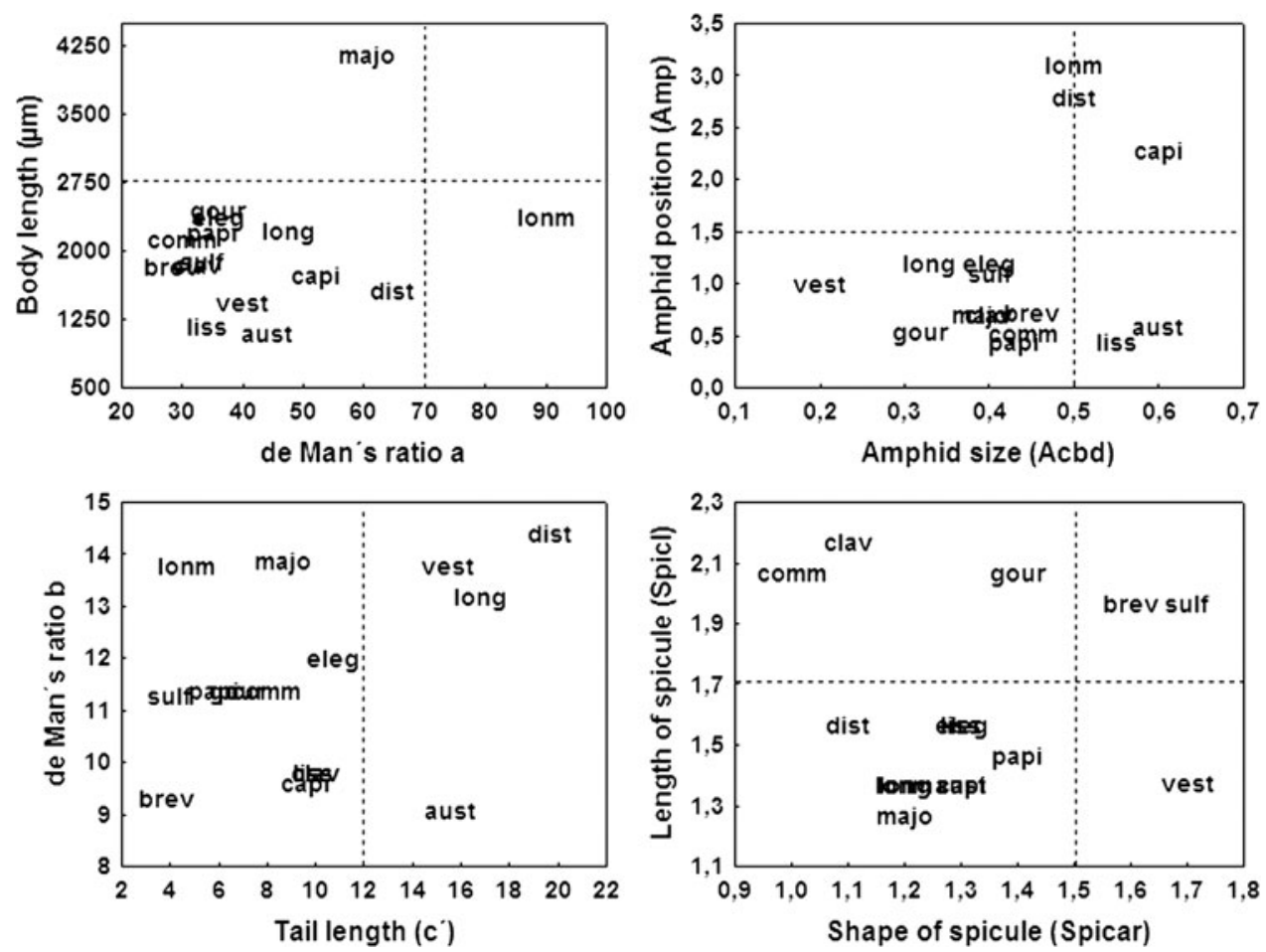

Fig. 1. Scatter plots of morphometric features of valid species of the genus Terschellingia. Measurements correspond to holotype. Labels defined as $3-4$ first types of the specific names in Table 3 (except for T. longisoma $=$ lonm). Dashed lines indicate possible cut-values for discriminating among species. 
Morphological characters would be highly useful in diagnosis of species. We selected six features: presence/absence of teeth, shape of cephalic setae (papilliform and setiform), presence/position of cervical setae (absent, at level of or posterior to amphidial fovea), presence/absence of pharyngeal bulb, developed/reduced apophysis and shape of the tail (conical portion less or more than 50\% of total length of tail). The number of developed ovaries appears to be a feature with taxonomic value, but it is not always described, mainly in old studies. The presence/pattern of precloacal supplements has been used extensively as a taxonomic character; although supplements are present in at least one species ( $T$. longicaudata) they are hard to observe with light microscope, and thus less useful as a diagnostic character.

\section{Discrimination of species within the genus Terschellingia}

Within the genus, 38 nominal species have been described. However, according to our results only 15 of them are considered as valid. From the 23 non-valid species, 14 are species inquirendae and nine are junior synonyms of one of the valid former species (see Table 2 for explanations). Pictorial (Figure 2) and tabular (Table 3) keys summarize the main diagnostic characters for discrimination among valid species of Terschellingia and an explanation follows below.

The presence of small teeth in the buccal cavity is the main taxonomic feature that distinguishes T. elegans and T. sulfidrica from the other species of the genus. Both species can be differentiated from one another by shape and length of spicules (more curved and larger in T. sulfidrica; Figures 1 \& 2), tail shape $(>50 \%$ conical in T. sulfidrica versus $>50 \%$ filiform in T. elegans), and the presence of a single ovary in T. sulfidrica. According to Gagarin \& Vu-Thanh (2003), T. elegans closely resembles $T$. supplementata (here synonymized with $T$. longicaudata) but mainly differs from it and in extension also from $T$. longicaudata by the presence of a tooth, the shorter cephalic setae and the absence of cervical setae.

Three species of Terschellingia have the amphidial fovea located relatively far from the anterior body end: T. capitata, $T$. distalamphida and T. longisoma (Figures 1 \& 2 ). Terschellingia distalamphida can be distinguished from the other two species by the presence of cervical setae and a filiforme tail $(<50 \%$ conical and more than 12 anal diameters length). Terschellingia capitata is characterized by a large and muscular pharyngeal bulb (bar 3.4 versus 1.3 and 1.9 in $T$. distalamphida and $T$. longisoma respectively). Terschellingia longisoma is characterized by a very long and thin body (total length holotype: $2156 \mu \mathrm{m}, \mathrm{a}=90$ ); also it has a tail very poorly attenuated to the terminus (Gagarin \& Vu-Thanh, 2006).

Terschellingia papillata is the only species of the genus with cephalic setae papilliforme. The spicules of $T$. papillata are very similar to those in T. longicaudata (Figure 2), but the former lacks the cervical setae and it has a larger conical portion of the tail.

On the basis of presence/absence of pharyngeal bulb, two groups of species can be distinguished: a group of ten species with clear set-off pharyngeal bulb (six of them already characterized above). The remaining four species (i.e. T. communis, T. lissa, T. longicaudata and T. vestigia) differ from each other by a combination of characters (Table 3).

Terschellingia lissa can be differentiated from the other three Terschellingia species by a larger size of amphidial fovea $(>0.5 \mathrm{cbd})$, conical portion of the tail is less than $50 \%$ of total length and lack of cervical setae. In addition T. lissa has a relatively small body length within the genus $(<1000 \mu \mathrm{m})$.

The main differences between T. communis and T. longicaudata rest on the length of the conical portion of the tail. The length of the tail appears to be useful for differentiating most of the specimens (i.e. T. communis $\mathrm{c}^{\prime}:<_{12}$; T. longicaudata $c^{\prime}:>12$; Figure 1). However, we recorded in Cienfuegos Bay some unusually large male specimens of $T$. longicaudata with 'short tail' (c': 5.5-8.8); and some females of T. communis can have a relatively long tail $\left(c^{\prime}: 10-12\right)$. The original description by de Man (1888) of $T$. communis showed a completely conical tail with pointed tip, not found in any other description of the species; the latter feature was discussed by Timm (1962) as 'problematic'. Reviewing the literature and based upon our own material, we found that the tail tip is rounded. The length of spicules appears to be an important feature for differentiating between the holotypes of $T$. communis and $T$. longicaudata (Figure 1). However, there are not clear differences between $T$. communis and T. longicaudata regarding spicule length on the basis of the few studies including absolute measurements: 54-61 $\mu \mathrm{m}$ (1.6$1.9 \mathrm{abd})$ versus $47-48 \mu \mathrm{m}(1.7 \mathrm{abd})$ in Warwick et al. (1998); $38-44 \mu \mathrm{m}(1.2-1.4$ abd) versus $38-113 \mu \mathrm{m}(1.4-$ $1.9 \mathrm{abd}$ ) in specimens from Cienfuegos Bay. However, since Figure 1 shows a clear cut-value around 1.7 abd for holotypes, we include the spicule length as a useful character for diagnosis.

Other important, but more difficult to standardize, differences between T. communis and T. longicaudata are regarding to cervical setae, shape of cardia, and shape of spicules and gubernaculum apophysis. So far, the main difference with respect to the pattern of cervical setae is the position (at level of amphidial fovea in T. longicaudata; posterior to the fovea in $T$. communis). However, the number of cervical setae and their relative position in the anterior region is variable in specimens of T. longicaudata as has been reported by other authors (e.g. Chitwood, 1951; Timm, 1961; Wieser \& Hopper, 1967; Bhadury et al., 2008) and from specimens from Cienfuegos Bay. The cardia is larger, rounded and without pericardiac cells in $T$. communis versus cylindrical and rounded by intestinal cells in T. longicaudata; nevertheless the shape would be affected by the processes of preservation and mounting for the specimen. In relation to accessorial reproductive structures, T. communis has a proximal end of spicules non-cephalated and the apophysis of gubernaculum wide and cuticularized in ventral border; $T$. longicaudata has a cephalated spicule with central septum in manubrium and a narrower apophysis of the gubernaculum. However, intraspecific variability in spicule shape and gubernaculum has been observed (i.e. compare T. communis in Figures $2 \mathrm{E} \& 3 \mathrm{E}$ ).

The high number of junior synonymies of T. longicaudata (in total five; see Table 2) could be explained by: (i) high abundance and cosmopolitan distribution leading to numerous descriptions by different authors; and (ii) high morphological plasticity. There are, for instance: large variation in body habitus (de Man's ratio a ranged 29-40 after Timm, 1962), 
Table 2. Outline of non-valid Terschellingia species. Abbreviations: sp. inq., species inquirenda; syn., synonymy. For additional abbreviations see Table 1. The numbers of specimens used in the original descriptions are indicated.

\begin{tabular}{|c|c|c|}
\hline Species & Conclusion & Comment \\
\hline T. antonovi Filipjev, 1922 & $\begin{array}{l}\text { syn. T. longicaudata } \\
\quad \text { (by Gerlach, 1963) }\end{array}$ & $\begin{array}{l}8 \mathrm{O}^{\top}, 9 \text { Q }, 11 \text { j; original descriptions match very well with current } \\
\text { diagnosis of T. longicaudata }\end{array}$ \\
\hline T. baltica Schulz, 1932 & sp. inq. (new) & $\begin{array}{l}1 O^{T} \text { poorly described, Timm (1962) synonymized it to } T \text {. } \\
\text { longicaudata, but original description is not sufficient for } \\
\text { determination beyond doubt }\end{array}$ \\
\hline T. baylisi Allgén, 1959 & sp. inq. (by Gerlach, 1963) & $1 \sigma^{\top}$ poorly described; cephalic sensilla not depicted \\
\hline T. exilis Cobb, 1888 & sp. inq. (new) & 1 poorly described, no illustration included \\
\hline T. falklandiae Allgén, 1959 & sp. inq. (by Gerlach, 1963) & $2 O^{1}$ poorly described; cephalic sensilla not depicted \\
\hline T. gerlachi Inglis, 1968 & syn. T. longicaudata (new) & $\begin{array}{l}1 O^{T} \text {, originally differentiated from } T \text {. longicaudata just upon } \\
\text { length of cephalic setae and presence of precloacal supplements }\end{array}$ \\
\hline T. glabricutis Platonova, 1971 & sp. inq. (new) & $\begin{array}{l}10 O^{7}, 10 \text {, absence of body setae appears to be a } \\
\text { misinterpretation due to mounting techniques used (glycerine/ } \\
\text { gelatine) }\end{array}$ \\
\hline T. heteroseta & syn. T. longicaudata (by & $60^{7}$; species diagnosis based on highly variable characters (length \\
\hline $\begin{array}{l}\text { Schuurmans-Stekhoven, } \\
1950\end{array}$ & Gerlach, 1963) & $\begin{array}{l}\text { of tail, size of cephalic setae and the amphidial fovea); } \\
\text { description matches closely } T \text {. longicaudata }\end{array}$ \\
\hline $\begin{array}{l}\text { T. heterospiculum Allgén, } \\
1933\end{array}$ & syn. T. communis (new) & $\begin{array}{l}1 O^{2} \text {, after Gerlach (1963) syn. of } T \text {. longicaudata; but position of } \\
\text { cervical setae behind amphidial fovea and the shape and length } \\
\text { of tail did not support this statement }\end{array}$ \\
\hline $\begin{array}{l}\text { T. longispiculata Wieser \& } \\
\text { Hopper, } 1967\end{array}$ & syn. T. longicaudata (new) & $\begin{array}{l}\text { The difference with } T \text {. longicaudata was longer spicules }(122 \mu \mathrm{m}) \text {, } \\
\text { however the shape is closely similar. } 2 O^{\prime} \text { from Cienfuegos Bay } \\
\text { with long spicules }(113 \mu \mathrm{m}) \text { underlined that this character is } \\
\text { highly variable }\end{array}$ \\
\hline $\begin{array}{l}\text { T. longissimicaudata Timm, } \\
1962\end{array}$ & sp. inq. (new) & $\begin{array}{l}1 O^{\top} \text {; the specimen resembles } T \text {. lissa; the only difference lies in the } \\
4 \text { cervical setae behind the amphids in T. longissimicaudata }\end{array}$ \\
\hline T. magna Timm, 1962 & sp. inq. (new) & $\begin{array}{l}1 \text {. The synonymy of T. communis described by Gerlach (1955) is } \\
\text { not valid due to differences in the amphidial fovea, cheilostome, } \\
\text { cervical setae and tip of the tail }\end{array}$ \\
\hline $\begin{array}{l}\text { T. maldivensis (Gerlach, 1963) } \\
\text { Austen, } 1989\end{array}$ & sp. inq. (new) & $\begin{array}{l}1 O^{\prime} \text {, sp. inq. because a single male was described, and the only } \\
\text { reliable diagnostic character was the absence of pharyngeal bulb }\end{array}$ \\
\hline T. minima Platonova, 1971 & sp. inq. (new) & $\begin{array}{l}6 O^{2}, 59 \text {, the description does not contain information on } \\
\text { pharyngeal bulb and ovaries. Also absence of setae appears to be } \\
\text { a misinterpretation due to employed techniques }\end{array}$ \\
\hline $\begin{array}{l}\text { T. monohystera Wieser \& } \\
\text { Hopper, } 1967\end{array}$ & syn. T. communis (new) & $\begin{array}{l}\text { A pseudo-monodelphic condition is not enough to state a new } \\
\text { species since in specimens of } T \text {. communis we recorded this } \\
\text { condition (see Table 4). Other characters match to T. communis }\end{array}$ \\
\hline T. mora Gerlach, 1956 & syn. T. communis (new) & $\begin{array}{l}1 O^{2}, 1 \text {, specimens resemble } T \text {. communis by Timm (1962) but } \\
\text { differed from the holotype in the absence of cervical setae; these } \\
\text { may be stout and therefore hard to detect }\end{array}$ \\
\hline T. parva Vitiello, 1969 & syn. T. communis (new) & $\begin{array}{l}3 \mathrm{O}^{2}, 2+, 3 \mathrm{j} \text {. The diagnostic character was the short body length } \\
(649-873 \mu \mathrm{m}) \text {; but the description of } T \text {. communis by Timm } \\
\text { (1962) indicated a similar size }(78 \mathrm{om}) \text {. The high plasticity of } \\
\text { Terschellingia suggests the low diagnostic value of the total } \\
\text { length of body }\end{array}$ \\
\hline T. paxi Schneider, 1939 & sp. inq. (new) & $\begin{array}{l}1 \text { O; poorly described. Species inquirenda because of absence of } \\
\text { male specimens, poor description and lack of discussion }\end{array}$ \\
\hline T. polaris Cobb, 1914 & sp. inq. (new) & $\begin{array}{l}1 O^{\top}, 19 \text {, poorly described. Amphidial fovea far from anterior end, } \\
\text { double wings in the cuticle, small size }(730-800 \mu \mathrm{m}) \text {. Probably } \\
\text { those specimens did not belong to the genus Terschellingia }\end{array}$ \\
\hline T. pontica Filipjev, 1918 & sp. inq. (new) & $\begin{array}{l}1 \text { Q description closely resembles } T \text {. longicaudata; however the } \\
\text { author stated that apparently the ends of ovaries were reflexed }\end{array}$ \\
\hline T. similis Allgén, 1933 & sp. inq (new) & $\begin{array}{l}1 \mathrm{j} \text {, the original description of the juvenile specimen resembles } \\
\text { closely T. longicaudata }\end{array}$ \\
\hline $\begin{array}{l}\text { T. supplementata Tchesunov, } \\
\quad 1978\end{array}$ & syn. T. longicaudata (new) & $\begin{array}{l}4 O^{\prime}, 3 \text { Q , specimens resemble T. longicaudata, only difference is } \\
\text { presence of precloacal supplements, but they have been reported } \\
\text { by Warwick et al. (1998), Pastor De Ward (1989) and in present } \\
\text { study }\end{array}$ \\
\hline T. viridis Timm, 1961 & sp. inq. (by Timm, 1962) & $\begin{array}{l}1 \text { Q after Timm (1962) the specimen probably belongs to another } \\
\text { genus due to the far posterior location of the amphidial fovea } \\
\text { (1.6 Amp), and a cardia very different from other species of } \\
\text { Terschellingia }\end{array}$ \\
\hline
\end{tabular}


A) T. austenae

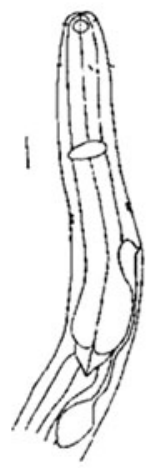

D) T. claviger

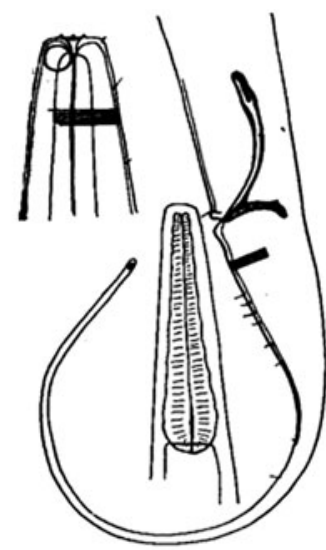

B) T. brevicauda

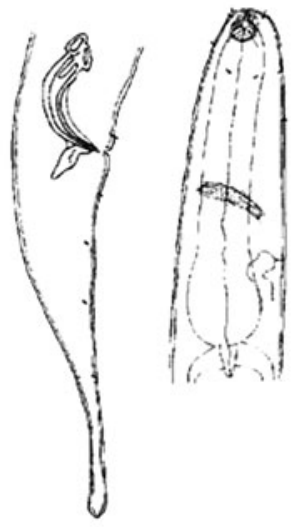

C) T. capitata

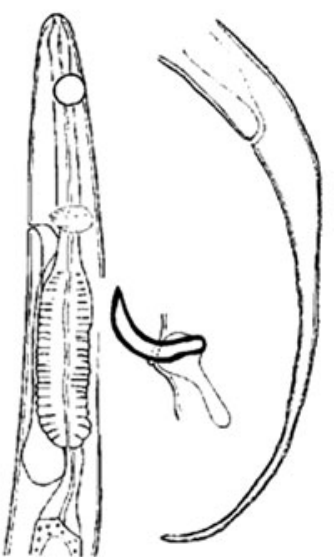

E) T. communis

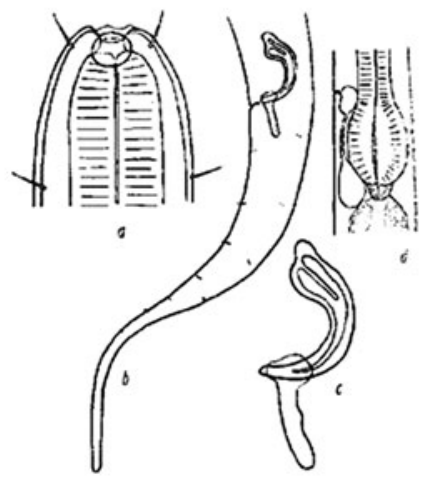

F) T. distalamphida
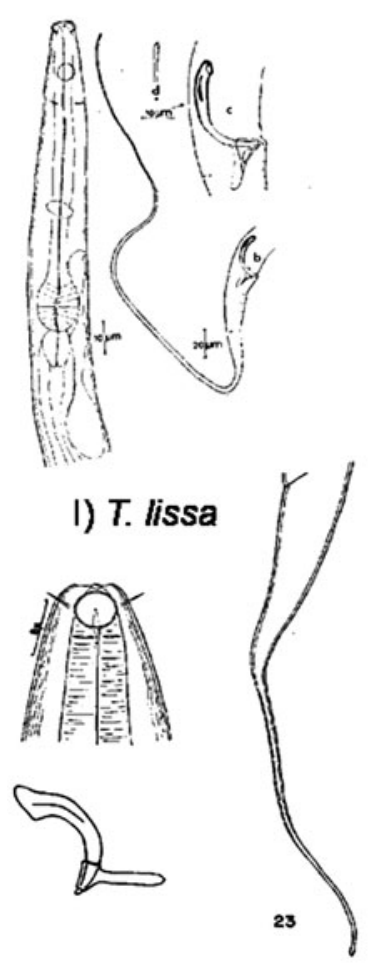

G) T. elegans
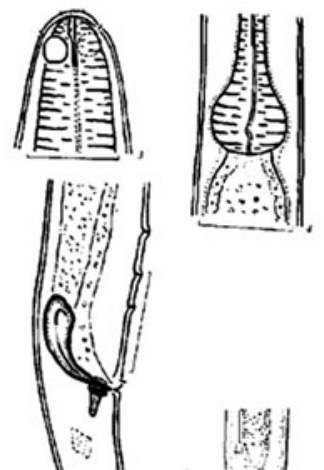

$\mid\left[\begin{array}{ll}3 \\ 3\end{array} \mid\right.$

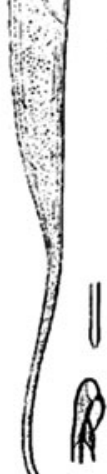

H) T. gourbaultae
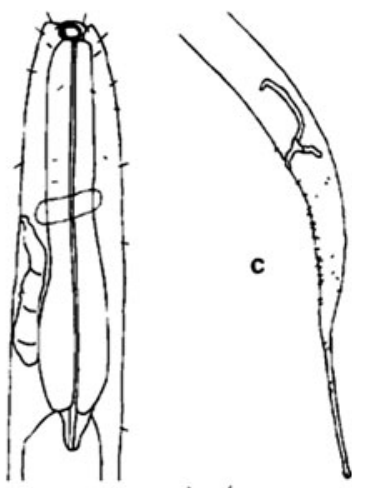

J) T. longicaudata

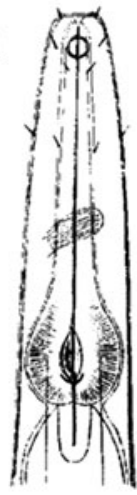

Fig. 2. Outline of 15 valid species of the genus Terschellingia. Drawings not to same scale and reproduced from original description (except for T. communis, reproduced from Gerlach, 1963). 
K) T. longisoma

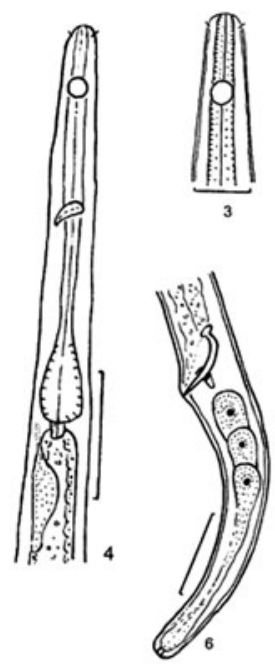

L) T. major

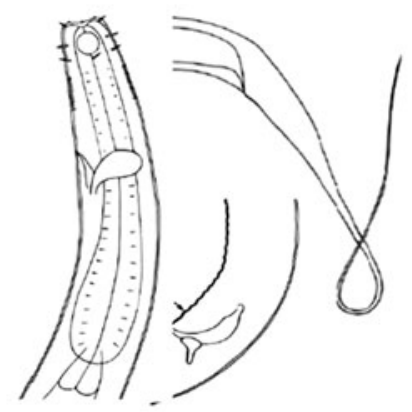

N) T. suffidrica

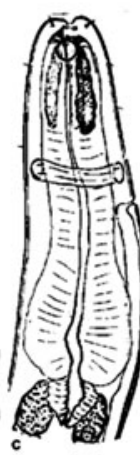

M) T. papillata

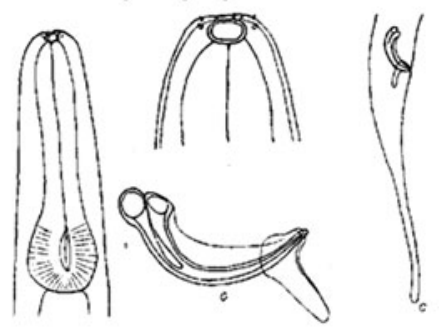

Fig. 2. (Continued)

sexual dimorphism in size of amphidial fovea $\left(\sigma^{7} 0.3 \mathrm{cbd} ; ~ ㅇ\right.$ 0.5 cbd after Wieser, 1956) and in relative position of amphidial fovea (Amp OT 0.5; $ᄋ$ o.9 after Vitiello, 1969), different aspect of spicular apparatus (Vitiello, 1969) and presence or absence of precloacal supplements.

The diagnosis of $T$. vestigia is based on the presence of a reduced dorsal apophysis of the gubernaculum. However, since only one male was described, putative intraspecific variability cannot be assessed. We prefer to maintain this species as valid given that it is relatively easy to check this diagnostic character.
Five species of Terschellingia lack a set-off pharyngeal bulb; the table elaborated by Austen (1989) and summarizing main differences among these species has been updated by Guo \& Zhang (2000) and Huang \& Zhang (2005) with addition of one species respectively but without further discussion. We found that some of the proposed diagnostic characters are less useful for species differentiation. Length-related measurements (total body length, de Man's ratio a and tail length) were notably overlapping among species. The body length is not a good main diagnostic character, even for species with extreme body sizes ( $T$. austenae $<950 \mu \mathrm{m} ;$ T. major $>$

Table 3. Main diagnostic characters differentiating the valid species of the genus Terschellingia de Man 1888. Abbreviations in Table 1; additional abbreviations: ceph. setae, shape of cephalic setae; cerv. setae, presence/position of cervical setae (first somatic setae) with respect to amphidial fovea; phar. bulb, pharyngeal bulb; post., posterior. States of character: $0=$ absence; $1=$ presence. * No females described.

\begin{tabular}{|c|c|c|c|c|c|c|c|c|c|c|}
\hline Species & Teeth & Amp & Acbd & Ceph. setae & Cerv setae & Phar bulb & Tcon $\%$ & Spicl & Apo-physis & Post ovary \\
\hline T. austenae Guo \& Zhang, 2000 & 0 & $<1.5$ & $>0.5$ & setiform & at level & $\mathrm{o}$ & $<50$ & $<1.7$ & developed & 1 \\
\hline T. brevicauda Ott, 1972 & 0 & $<1.5$ & $\leq 0.5$ & setiform & behind & o & $>_{50}$ & $>_{1.7}$ & developed & 1 \\
\hline T. capitata Vitiello, 1969 & 0 & $>_{1.5}$ & $>0.5$ & setiform & absent & 1 & $>_{50}$ & $<1.7$ & developed & * \\
\hline T. claviger Wieser, 1956 & 0 & $<1.5$ & $\leq 0.5$ & setiform & behind & o & $<50$ & $>_{1.7}$ & developed & * \\
\hline T. communis de Man, 1888 & 0 & $<1.5$ & $\leq 0.5$ & setiform & behind & 1 & $>_{50}$ & $>1.7$ & developed & 1 \\
\hline T. distalamphida Juario, 1974 & 0 & $>1.5$ & $\leq 0.5$ & setiform & behind & 1 & $<50$ & $<1.7$ & developed & 1 \\
\hline T. elegans Gagarin \& Vu-Thanh, 2003 & 1 & $<1.5$ & $\leq 0.5$ & setiform & absent & 1 & $<50$ & $<1.7$ & developed & 1 \\
\hline T. gourbaultae Austen, 1989 & 0 & $<1.5$ & $\leq 0.5$ & setiform & at level & 0 & $>_{50}$ & $>_{1.7}$ & developed & 1 \\
\hline T. lissa Timm, 1962 & 0 & $<1.5$ & $>0.5$ & setiform & absent & 1 & $<50$ & $<1.7$ & developed & 1 \\
\hline T. longicaudata de Man, 1906 & o & $<1.5$ & $\leq 0.5$ & setiform & at level & 1 & $<50$ & $<1.7$ & developed & 1 \\
\hline T. longisoma Gagarin \& Vu-Thanh, 2006 & 0 & $>1.5$ & $>0.5$ & setiform & absent & 1 & $>_{50}$ & $<1.7$ & developed & 1 \\
\hline T. major Huang \& Zhang, 2005 & 0 & $<1.5$ & $\leq 0.5$ & setiform & at level & 0 & $>_{50}$ & $<1.7$ & developed & 1 \\
\hline T. papillata Gerlach, 1955 & 0 & $<1.5$ & $\leq 0.5$ & papilliform & absent & 1 & $>_{50}$ & $<1.7$ & developed & 1 \\
\hline T. sulfidrica Pastor de Ward, 1989 & 1 & $<1.5$ & $\leq 0.5$ & setiform & behind & 1 & $>_{50}$ & $>1.7$ & developed & 0 \\
\hline T. vestigia Gerlach, 1963 & 0 & $<1.5$ & $>0.5$ & setiform & at level & 1 & $<50$ & $<1.7$ & reduced & 1 \\
\hline
\end{tabular}



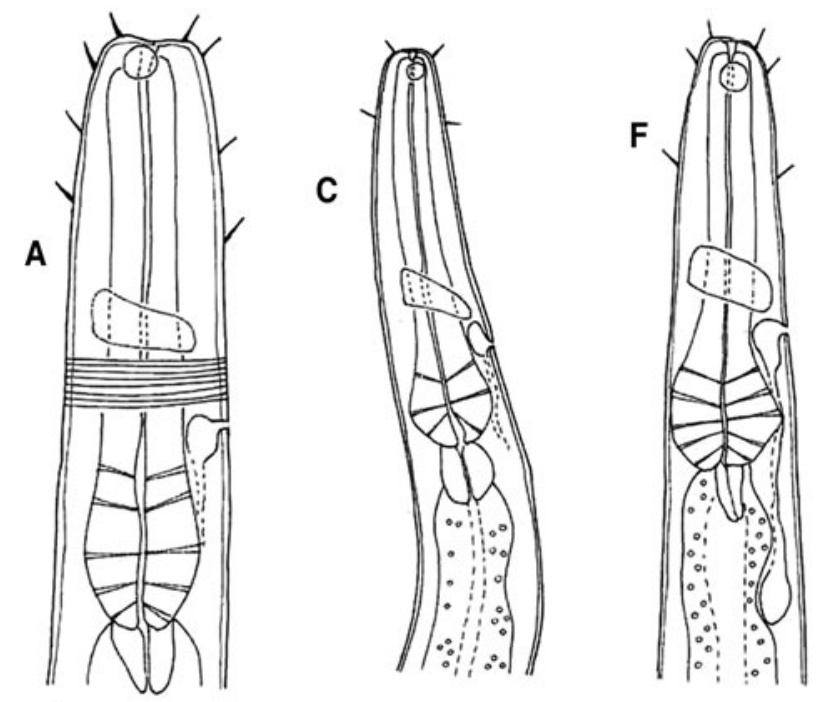

\section{$50 \mu \mathrm{m}$ \\ A-D, F, G}

\section{$10 \mu \mathrm{m}$ \\ $\overline{E, H}$}
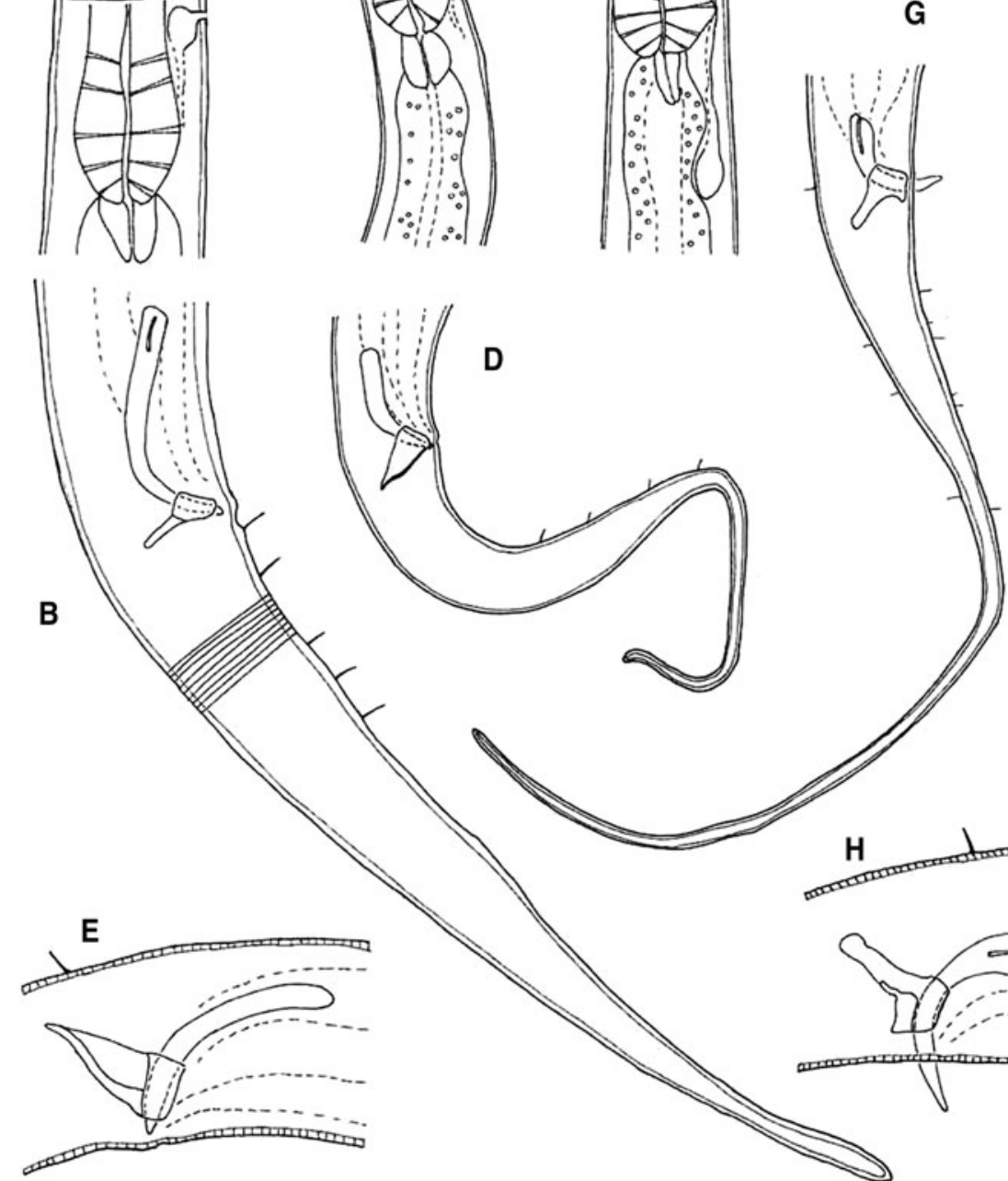

G

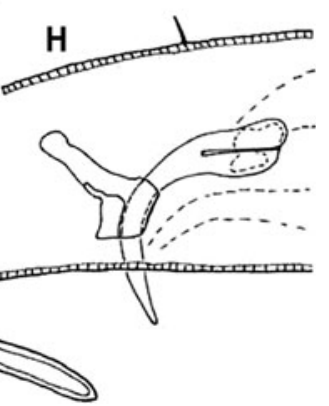

Fig. 3. Species of the genus Terschellingia recorded in Cienfuegos Bay, Caribbean Sea. T. gourbaultae: (A) anterior part; (B) tail; (G) spicular apparatus; T. communis: (C) anterior part; (D) tail; (E) spicular apparatus; T. longicaudata: (F) anterior part; (G) tail; (H) spicular apparatus.

$3436 \mu \mathrm{m})$ since in some monhysterids, body size is influenced by environmental factors such as food availability (dos Santos et al., 2008). In addition, the length of spicules in five specimens of T. gourbaultae from Cienfuegos Bay was shorter $(59-66 \mu \mathrm{m})$ than specimens from the Tamar Estuary, England reported by Austen (1989) $(80-88 \mu \mathrm{m})$, suggesting high variability in this character.

Two species (T. austenae and $T$. claviger) have less than $50 \%$ of total tail length conical, with the distal third portion filiforme. These species can be differentiated from each other by the relative size of amphidial fovea and the position of cervical setae; in addition, the length and shape of spicules and apophysis of gubernaculum would be useful diagnostic characters (Table 3 ).
Differences among $T$. brevicauda, T. gourbaultae and $T$. major are more subtle on the basis of taxonomic characters currently proposed. Austen (1989) pointed out that the shorter tail in T. brevicauda ( $\left.c^{\prime} 3.5-4.3\right)$ allows its differentiation from other species; the tail of T. gourbaultae is effectively larger ( $c^{\prime}$ : 5.5-8.0 after Austen; 5.1-9.4 in specimens from Cienfuegos Bay). An additional feature, maybe less variable (and so more useful), is the position of the cervical setae (Table 3). The spicular apparatus is different in appearance (Figure 2) and in absolute measures (spicule length: 47$53 \mu \mathrm{m}$ for $T$. brevicauda versus $80-88 \mu \mathrm{m}$ for T. gourbaultae), but other morphometric measures such as relative length and shape of spicules failed to show differences (Figure 1). The unique record of $T$. brevicauda in North 
Carolina, USA (Ott, 1972) does not allow to assess possible intraspecific variability.

Two conspicuous features allow to identify specimens belonging to T. major; i.e. large body size $(>3000 \mu \mathrm{m})$, and presence of precloacal supplements $\left(>_{30}\right)$. The latter character has been recorded in T. sulfidrica; but in specimens described from several geographical regions (e.g. T. longicaudata) the presence and number of supplements appeared variable. On the basis of the proposed differential diagnosis for species of Terschellingia (Table 3) the discrimination between T. gourbaultae and T. major would become problematic if high intraspecific variability exists in the latter species. The differences in relative length of spicules between holotypes suggest the usefulness of this feature for discrimination (Figure 1).

\section{Description of Terschellingia species from Cienfuegos Bay}

For most of the features measured on specimens from Cienfuegos Bay they were relatively different from the data for the holotypes. This suggests a continuum in the size of body structures and a high morphological plasticity in the three species analysed. The high morphological plasticity in some nematode genera with numerical dominance (e.g. Daptonema, Sabatieria and Terschellingia) could adjust in a more general model relating morphological plasticity and ecological success (Hollander, 2008 and references herein). It should be interesting to assess the level of intraspecific variability (i.e. morphological plasticity) in rarer species of nematodes; and also to test for relationships between morphological plasticity and ecological dominance in free-living marine nematodes.
The morphometric data are presented in Table 4 and illustrations in Figure 3. We only include in this section those features with some variation compared to older descriptions of the species.

\section{TERSCHELLINGIA COMMUNIS DEMAN, 1888}

Material measured: $3 \bigcirc^{7} ; 4$ O ; 2 j

Remarks. Body length of juveniles: 1000-1125 $\mu \mathrm{m}$; differentiation between juvenile stages could not be determined beyond doubt. The degree of development of ovaries was variable either anterior ovary more developed than posterior one, reverse or equally developed. The shape of the spicules and gubernaculum apophyses shows variability in some details among the descriptions by de Man (1888), Timm (1962), Gerlach (1963) and our observations. A conspicuous feature is presence of a developed cardia between pharynx and intestine (however, the shape sometimes appears to be affected by preservation or physiological condition of the specimen). This character has not been pointed out by the earlier descriptions of the species but could be a useful character for identification.

\section{TERSCHELLINGIA GDURBAULTAE AUSTEN 1989}

Material measured: $5 \mathrm{O}^{7} ; 3$ O; $4 \mathrm{j}$.

Remarks. T. gourbaultae has been described relatively recently and was recorded only in British and French estuaries. Body length of juveniles: 767-2125 $\mu \mathrm{m}$; differentiation

Table 4. Morphometric data (minimum-maximum) for males and females of Cuban specimens of the genus Terschellingia. Abbreviations in Table 1; additional abbreviations: amph $\varnothing$, diameter of amphidial fovea; amp.dist, distance of amphidial fovea to anterior end; gubern., gubernaculum; spic.arc and spic.cor, length of spicules as arc and cord respectively.

\begin{tabular}{|c|c|c|c|c|c|c|}
\hline \multirow[t]{2}{*}{ Feature } & \multicolumn{2}{|c|}{ T. communis } & \multicolumn{2}{|c|}{ T. gourbaultae } & \multicolumn{2}{|c|}{ T. longicaudata } \\
\hline & $3 \sigma^{7}$ & 49 & $5 \sigma^{x}$ & $5 q$ & $10 \sigma^{\pi}$ & 5 ㅇ \\
\hline Body length $(\mu \mathrm{m})$ & $1313-1400$ & $1125-2000$ & $1563-2063$ & $1563-2500$ & $1367-2438$ & $1267-1750$ \\
\hline A & $31.1-32.8$ & $22.0-38.9$ & $25.9-31.2$ & $21.6-33.5$ & $25.9-44.9$ & $27.8-45.0$ \\
\hline $\mathrm{b}$ & $12.4-13.8$ & $12.0-14.4$ & $9.6-11.5$ & $9.6-3.3$ & $11.5-13.9$ & $12.0-14.7$ \\
\hline c & $5.0-5.6$ & $4.5-8.9$ & $5.2-7.8$ & $4.6-6.0$ & $2.2-7.8$ & $2.5-3.5$ \\
\hline Cephalic setae $(\mu \mathrm{m})$ & $4-6$ & $4-6$ & $4-8$ & $4-9$ & $2-7$ & $5-8$ \\
\hline Amph $\varnothing(\mu \mathrm{m})$ & $4-5$ & $4-5$ & $9-12$ & $7-10$ & $7-9$ & $5-10$ \\
\hline Acbd & 0.3 & $0.2-0.3$ & 0.3 & $0.2-0.3$ & $0.3-0.5$ & $0.3-0.5$ \\
\hline Amp.dist $(\mu \mathrm{m})$ & $4-5$ & $2-5$ & $5-10$ & $4-12$ & $3-8$ & $2-6$ \\
\hline Amp & 1.0 & $0.5-1.3$ & $0.5-1.0$ & $0.6-1.6$ & $0.4-1.0$ & $0.3-0.9$ \\
\hline Nerv \% & $55-65$ & $47-69$ & $34-57$ & $39-54$ & $40-61$ & $44-58$ \\
\hline Excp \% & $78-83$ & $69-75$ & $50-79$ & $61-71$ & $57-76$ & $65-68$ \\
\hline Tail length $(\mu \mathrm{m})$ & $233-275$ & $225-263$ & $233-333$ & $313-433$ & $313-488$ & $367-688$ \\
\hline$\dot{c}$ & $8.0-8.9$ & $6.1-11.9$ & $5.1-6.5$ & $6.5-9.4$ & $5.5-18.0$ & $15.5-23.1$ \\
\hline Tcon $\%$ & $55-73$ & $50-72$ & $58-79$ & $44-71$ & $17-62$ & $18-42$ \\
\hline Testis length $(\mu \mathrm{m})$ & $733-767$ & & $938-1267$ & & $533-1313$ & \\
\hline $\mathrm{T} \%$ & $55-65$ & & $47-68$ & & $39-51$ & \\
\hline Spic.arc $(\mu \mathrm{m})$ & $38-44$ & & $75-88$ & & $38-113$ & \\
\hline Spicl & $1.2-1.4$ & & $1.4-1.9$ & & $1.4-1.9$ & \\
\hline Spic.cor $(\mu \mathrm{m})$ & $31-33$ & & $59-66$ & & $25-86$ & \\
\hline Spicar & $1.2-1.3$ & & $1.1-1.5$ & & $1.4-1.6$ & \\
\hline Gubern. length $(\mu \mathrm{m})$ & $10-11$ & & $11-13$ & & $5-21$ & \\
\hline Apophysis length $(\mu \mathrm{m})$ & $14-18$ & & $17-24$ & & $13-29$ & \\
\hline $\mathrm{G}_{1} \%$ & & $5-19$ & & $7-31$ & & $5-14$ \\
\hline $\mathrm{G}_{2} \%$ & & $5-15$ & & $5-29$ & & $5-14$ \\
\hline V \% & & $44-62$ & & $45-48$ & & $38-47$ \\
\hline
\end{tabular}


between juvenile stages could not be determined beyond doubt. The pattern of cervical setae described for holotype (i.e. three circles of cervical setae each one with eight setae) was common; but presence of only a single circle also occurred as well as a reduction in number of setae per circle (to 4-6). The specimens from Cienfuegos Bay closely resemble the holotype, except for the proximal end of the spicule. This suggests that morphological details of accessory reproductive structures have to be interpreted with caution since they can vary among populations.

\section{TERSCHELLINGIA LONGICAUDATA DEMAN 1906}

Material measured: $10 \bigcirc^{7}, 5$ ㅇ, $6 \mathrm{j}$.

Remarks. The specimens of $T$. longicaudata collected at Cienfuegos Bay closely resemble the original description of the holotype. Total length of juveniles: 733-1188 $\mu \mathrm{m}$. Main differences are with regard to the pattern of cervical setae and shorter length of cephalic setae in juveniles. The intestine is often filled with conspicuous green granules all over its length. Precloacal supplements present, visible as small pits (6-7 in number) in large specimens using light microscopy; in smaller specimens only visible by scanning electron microscopy (results not shown). Two large-sized male specimens $(4280$ and $4800 \mu \mathrm{m})$ of Terschellingia were described by Murphy (1965) who suggested that they belong to T. communis. However, those specimens were similar to T. longicaudata in the habitus, pattern of anterior sensilla, and shape and size of spicules; the main difference was the length of the tail $\left(c^{\prime}: 7\right)$. We also collected two large males (2375 and $2438 \mu \mathrm{m}$ ) with tail unusually short ( $c^{\prime}: 5.5$ and 8.6) and large spicules (113 $\mu \mathrm{m}$ both specimens). A recent study (Bhadury et al., 2008), combining morphological and molecular tools points to the presence of cryptic species of T. longicaudata. In our study, the exploration of ultrastructure-based characters by SEM (as suggested by Bhadury et al., 2008) did not add any additional character of diagnostic value for discrimination among putatively cryptic species of $T$. longicaudata. Therefore, future refining of molecular techniques on this species (in combination with morphological analysis) is the most promising way forward for dealing with this taxonomically problematic species.

\section{ACKNDWLEDGEMENTS}

Financial support was provided by the International Foundation for Science (research grant IFS A-4004/1 to M. Armenteros), and Ghent University (doctoral scholarship BOF 01 W01607 to M. Armenteros; project BOF 01GZ0705 'Biogeography and Biodiversity of the Sea' to M. Vincx). The Belgian Focal Point to the Global Taxonomy Initiative (project 2406JVG2) powered the taxonomic expertise in nematodes of the Cuban authors. We thank staff of the Center for Environmental Studies of Cienfuegos (CEAC) for the valuable collaboration, particularly R. Fernández-Garcés (Cacho) and L. Díaz-Asencio for help with sampling and initial processing of samples. Our colleagues C. Pastor de Ward, and A. Tchesunov kindly provided us with valuable literature. Thanks to Marjolein Couvreur for assistance with the microscopy. We acknowledge two anonymous referees who improved considerably the manuscript with their comments.

\section{REFERENCES}

Allgén C.A. (1933) Freilebende nematoden aus dem Tronhjemsfjord. Capita Zoologica 4, 1-162.

Allgén C.A. (1959) Free-living marine nematodes. In Odhner N.Hj. (ed.) Further zoological results of the Swedish Antarctic expedition 19011903. Stockholm: Kungl. Boktryckeriet P.A. Norstedt \& Söner, pp. $1-295$.

Alroy J. (2002) How many named species are valid? Proceedings of the National Academy of Sciences of the United States of America 99, $3706-3711$.

Austen M.C. (1989) New species of Terschellingia (Nematoda: Linhomoeidae) from the Tamar Estuary, England and the Maldive Islands. Journal of the Marine Biological Association of the United Kingdom 69, 93-99.

Bhadury P., Austen M.C., Bilton D.T., Lambshead P.J.D., Rogers A.D. and Smerdon G.R. (2008) Evaluation of combined morphological and molecular techniques for marine nematode (Terschellingia spp.) identification. Marine Biology 154, 509-518.

Chitwood B.G. (1951) North American marine nematodes. Texas Journal of Sciences 3, 617-672.

Cobb N.A. (1888) Australian free-living marine nematodes. Proceedings of the Linnean Society of New South Wales 23, 33-407.

Cobb N.A. (1914) Antarctic marine free-living nematodes of the Shackleton expedition. Contributions to a Science of Nematology 1, $1-33$.

De Ley P. (2000) Lost in worm space: phylogeny and morphology as road maps to nematode diversity. Nematology 2, 9-16.

De Man J.G. (1888) Sur quelques nématodes libres de la Mer du Nord, nouveaux ou peu connus. Mémoires de la Société Zoologique de France 1, 1-51.

De Man J.G. (1906) Sur quelques espèces nouvelles ou peu connues de nématodes libres vivant sur les côtes de la 25 ocieta. Mémoires de la Société Zoologique de France 20, 33-90.

Deprez T., Vanden Berghe E. and Vincx M. (2004) NeMys: a multidisciplinary biological information system. In Vanden Berghe (ed.) Proceedings: 'The Colour of Ocean Data': International symposium on oceanographic data and information management with special attention to biological data, Brussels, Belgium, 25-27 November 2002. IOC Workshop Report, pp. 57-63.

Derycke S., Remerie T., Vierstraete A., Backeljau T., Vanfleteren J., Vincx M. and Moens T. (2005) Mitochondrial DNA variation and cryptic speciation within the free-living marine nematode Pellioditis marina. Marine Ecology Progress Series 300, 91-103.

Dos Santos G.A.P., Derycke S., Fonsêca-Genevois V.G., Coelho L.C.B.B., Correia M.T.S. and Moens T. (2008) Differential effects of food availability on population growth and fitness of three species of estuarine, bacterial-feeding nematodes. Journal of Experimental Marine Biology and Ecology 355, 27-40.

Filipjev I.N. (1918) Free-living marine nematodes of the Sevastopol area. Transactions of the Zoological Laboratory and the Sevastopol Biological Station of the Russian Academy of Sciences Series II, 4.

Filipjev I.N. (1922) Sur les Nématodes libres de la mer d'Azov. Trudy Stavropol'skogo Sel'skohozyaystvennogo Instituta 1, 185-208.

Fortuner R. (1990) Ratios and indexes in nematode taxonomy. Nematologica 36, 205-216. 
Gagarin V.G. and Vu-Thanh N. (2003) Three new species of free-living nematodes from Vietnamese water bodies. Zoologicheskii Zhurnal 82, $1393-1401$.

Gerlach S.A. (1955) Zur kenntnis der freilebenden marinen nematoden von San Salvador. Zeitschrift für Wissenschaftliche Zoologie 158, $249-303$.

Gerlach S.A. (1956) Brasilianische meeres-nematoden 1. Boletim do Instituto Oceanográfico São Paulo 5, 3-69.

Gerlach S.A. (1963) Über freilebende meeresnematoden revision der Linhomoheidae. Zoologische Jahrbücher Systematik Band 90, 599-658.

Gerlach S.A. and Riemann F. (1973) The Bremerhaven checklist of aquatic nematodes. A catalogue of Nematoda Adenophorea excluding the Dorylaimida. Bremen: Kommissionsverlag Franz Leuwer.

Guo Y. and Zhang Z. (2000) A new species of Terschellingia (Nematoda) from the Bohai Sea, China. Journal of Ocean University of Qingdao 30, $487-492$

Heip C., Vincx M. and Vranken G. (1985) The ecology of marine nematodes. Oceanography and Marine Biology: an Annual Review $23,399-489$.

Hollander J. (2008) Testing the grain-size model for the evolution of phenotypic plasticity. Evolution, doi: 10.1111/j.1558-5646.2008.00365.x.

Huang Y. and Zhang Z. (2005) Two new species and one new record of free-living marine nematodes from the Yellow Sea, China. Cahiers de Biologie Marine 46, 365-378.

Inglis W.G. (1968) Interstitial nematodes from St. Vincent's Bay, New Caledonia. Expédition française sur les recifs coralliens de la Nouvelle Calédonie, Paris 1967, Editions de la Fondation Singer-Polignac, Occasional Publications, No. 2, 45 pp.

Juario J. (1974) Neue freilebende Nematoden aus dem Sublitoral der Deutschen Bucht. Veröffentlichungen Des Instituts für Meeresforschung in Bremerhaven 14, 275-303.

Lorenzen S. (1994) The phylogenetic systematics of freeliving nematodes. Andover: The Ray Society.

Murphy D.G. (1965) Chilean marine nematodes. Veröffentlichungen des Instituts für Meeresforschung in Bremerhaven 9, 173-203.

Nadler S.A. (2002) Species delimitation and nematode biodiversity: phylogenies rule. Nematology 4, 615-625.

Ott J.A. (1972) Twelve new species of nematodes from an intertidal sandflat in North Carolina. Internationale Revue der Gesamten Hydrobiologie und Hydrographie 57, 463-496.

Pastor de Ward C. (1989) Free-living marine nematodes of the Deseado River Estuary (Siphonolaimoidea, Siphonolaimidae, Linhomoeidae) Santa Cruz, Argentina. 6. Studies on Neotropical Fauna and Environment 24, 231-247.
Platonova T.A. (1971) Free-living marine nematodes from the Possjet Bay of the Sea of Japan. Isledovanija Fauni Morjei 8, 72-108.

Schneider G. (1926) Zweiter Beitrag zur Kenntnis der Brackwasser-Nematoden Finlands. Acta Ocietatis pro fauna et flora Fennica 56, 1-47.

Schneider W. (1939) Eine neue Terschellingia-Art aus den Thermen von Split. Godišnjak Oceanografskog Instituta Kraljevine Jugoslavije 2, $101-103$.

Schulz E. (1932) Beiträge zur Kenntnis mariner Nematoden aus der Kieler Butch. Zoologische Jahrbücher Systematik Band 62, 331-340.

Schuurmans-Steckhoven J.H. (1950) The freeliving marine nemas of the Mediterranean. I. The Bay of Villefranche. Mémoires de Institut Royal des Sciences Naturelles de Belgique 10, 1-220.

Tchesunov A.V. (1978) Free-living nematodes of the family Linhomoeidae from the Caspian Sea. Zoologicheskii Zhurnal 57, $1623-1631$

Timm R.W. (1961) The marine nematodes of the Bay of Bengal. Proceedings of the Pakistan Academy of Science 1, 25-88.

Timm R.W. (1962) Marine nematodes of the family Linhomoeidae from the Arabian Sea at Karachi. Canadian Journal of Zoology 40, 165-178.

Vitiello P. (1969) Linhomoeidae (Nematoda) des vases profondes du Golfe du Lion. Thetys 1, 493-527.

Warwick R.M., Platt H.M. and Somerfield P.J. (1998) Free-living marine nematodes. Part III. Monhysterids. Shrewsbury: Field Studies Council.

Wieser W. (1956) Free living marine nematodes. III. Axonolaimoidea and Monhysteroidea. Reports of the Lund University Expedition 1948-49. Lunds Universitets Arsskrift, No. 52, 115 pp.

Wieser W. and Hopper B. (1967) Marine nematodes of the east coast of North America. I. Florida. Bulletin of the Museum of Comparative Zoology (Harvard University) 135, 239-344.

and

Yushin V.V. (2008) Sperm dimorphism in the free-living marine nematode Terschellingia glabricutis (Nematoda: Monhysterida: Linhomoeidae). Nematology 10, 189-205.

\section{Correspondence should be addressed to:}

W. Decraemer

Nematology Section

Ghent University, Ledeganckstraat 35

9000 Ghent

Belgium

email: wilfrida.decraemer@ugent.be 